\title{
Phytochemical and Antibacterial Properties of Leaf Extract of Stereospermum kunthianum (Bignoniaceae)
}

\author{
${ }^{* 1}$ M.S. Aliyu, ${ }^{2}$ U.A. Hanwa, ${ }^{1}$ M.B.Tijjani, ${ }^{3}$ A.B. Aliyu, and ${ }^{4}$ B. Ya'u \\ ${ }^{1}$ Department of Microbiology, ${ }^{2}$ Department of Pharmaceutical and Medicinal Chemistry, \\ ${ }^{3}$ Department of Chemistry, Ahmadu Bello University, Zaria \\ ${ }^{4}$ Department of Science Laboratory Technology, Nuhu Bamalli Polytechnic, Zaria \\ [*Corresponding author's e-mail: msaliyuzra@gmail.com, Phone no. +2348022360774]
}

\begin{abstract}
Phytochemical screening and studies on antibacterial activity of leave extract of Stereospermum kunthianum -a plant widely used by traditional medical practitioners in Northern Nigeria, were carried out on Escherichia coli, Staphylococcus aureus, Pseudomonas aeruginosa, Klebsiella spp, Salmonella spp and Aeromonas hydrophila using agar well diffusion technique. Preliminary phytochemical screening revealed the presence of sterols, coumarins, higher fatty acids and the absence of flavones aglycone and alkaloids in the leave extract. The activity of the extract was more potent at 30 $\mathrm{mgml}^{-1}$ with zone of growth inhibition against $S$. aureus $(35 \mathrm{~mm})$, Klebsiella spp $(28 \mathrm{~mm})$ and $A$. hydrophila $(28 \mathrm{~mm})$. The least activity was on $P$. aeruginosa $(9 \mathrm{~mm})$. The minimum inhibitory concentration (MIC) of the extract was $2.09 \mathrm{mgml}^{-1}$ on Klebsiella spp and $S$. aureus while $4.17 \mathrm{mgml}^{-1}$ on Salmonella spp and A. hydrophila. Similarly, the minimal bactericidal concentration (MBC) was 2.09 $\mathrm{mgml}^{-1}$ on S. aureus and $4.17 \mathrm{mgml}^{-1}$ on Klebsiella spp. However, higher MIC and MBC of $16.67 \mathrm{mgml}^{-1}$ were observed on $P$. aeruginosa. The spectra of activities displayed by the extract can be attributed to the presence of these phytochemicals which signifies the potential of $S$. Kunthianum as a source of therapeutic agents. This therefore, supports the traditional medicinal use of S. kunthianum in Zaria, Nigeria.
\end{abstract}

KEYWORDS: Stereospermum kunthianum, phytochemical, antibacterial activity, Bignoniaceae

\section{INTRODUCTION}

The use of plants for medicinal purposes is an age old tradition in Africa (Karou, et al., 2006). Today, more than $70 \%$ of the people in Africa refer to traditional healers concerning health issues (Kamanzy et al., 2002). The World Health Organization (WHO) encourages the inclusion of herbal medicines of proven safety and efficacy in the healthcare programs of developing countries because of the great potential they hold in combating various diseases (Amos et al., 2001). Plant extracts represent a continuous effort to find new compounds with the potential to act against multi-resistant bacteria. Approximately $20 \%$ of the plants found in the world have been submitted to pharmacological or biological test, and a substantial number of new antibiotics introduced on the market are obtained from natural or semisynthetic resources (Mothana and Lindequist, 2005). Thus, it is anticipated that phytochemicals with adequate antibacterial efficacy will be used for the treatment of bacterial infections.
Stereospermum kunthianum is a deciduous shrub or tree found in the dry areas of deciduous forest, woodland, bush, rocky outcrops, termite mound and margins of evergreen forests. The plant is known locally as Sansami (Hausa) and is widely used by traditional medical practitioners in Northern Nigeria for the treatment of various human diseases. The pods are chewed with salt to treat coughs and are used in treatment of ulcers, leprosy, skin eruptions and venereal diseases, while the stem bark decoction or infusion is used to cure bronchitis, pneumonia, cough, rheumatic arthritis and dysentery (Gill, 1992). The twigs are chewed to clean teeth and to treat toothache. The roots and leaves have been found useful in treating venereal diseases, respiratory ailments, gastritis (Gill, 1992) and a disease called "Rana" with symptoms of haematuria (Dalziel, 1955). Previously, the antiplasmodial activities of naphthaquinones and one anthraquinone from the lipophilic root bark extract was reported (Onegi et al., 2002). Antidiarrhoeal (Ching et al., 2008), 
analgesic activities of stem bark (Ching et al., 2009), as well as the anthelmintic activity of ethanol leave extract has been reported (Monglo et al., 2006).The present study therefore, reports the phytochemical screening and antibacterial activity of the lipophilic leaves extract of Stereospermum kunthianum with a view to understanding the molecular basis of some of its therapeutic uses in traditional medicine, which had not been investigated hitherto.

\section{MATERIALS AND METHODS \\ Collection and identification of plant material}

Whole fresh plant bearing fruits and leaves growing wild was collected in Zaria in December, 2005. The plant was authenticated at the herbarium unit of the Department of Biological Sciences, Ahmadu Bello University, Zaria, where a voucher number 1381 was deposited. Leaves were air dried at room temperature for 21 days to a constant weight. The dried leaves were pulverized to coarse powder using mortar and pestle and sieved with 20 mesh (British standard). The powdered leaves were stored for further studies.

\section{Extraction}

One hundred and sixty five grams (165 g) of the powdered leaves were soxhlet extracted with petroleum ether $\left(60-80^{\circ} \mathrm{C}\right)$ until the draining solvent was clear (Chhabra, et al., 1982). The solvent was removed under reduced pressure below $50^{\circ} \mathrm{C}$ to give a crude extract. The crude extract was further dried in vacuum desiccator over anhydrous copper sulphate to give a dry solid of the extract $(6.64 \mathrm{~g})$. This was used for phytochemical screening and bioassay.

\section{Phytochemical screening}

Phytochemical screening of the extract was carried out to identify the constituents, using standard phytochemical methods as described by Sofowora (1993) and Trease and Evans (1996).

\section{Evaluation of antimicrobial activity}

Clinical isolates of Pseudomonas aeruginosa, Staphylococcus aureus, Escherichia coli, Salmonella spp, Aeromonas hydrophila and Klebsiella spp were obtained from the Department of Microbiology, Ahmadu Bello University, Zaria. The susceptibilities of the test organisms to the plant extract were assayed as described by Karou et al. (2006). Briefly, the test organisms from growth on nutrient agar incubated at $37^{\circ} \mathrm{C}$ for $18 \mathrm{hr}$ were suspended in saline solution $(0.85 \% \mathrm{NaCl})$ and adjusted to match a turbidity of $0.5\left(10^{8}\right.$ cells $/ \mathrm{ml}$ ) McFarland standard. The standardized suspension was used to inoculate the surfaces of Mueller Hinton agar plates $(90 \mathrm{~mm}$ in diameter) using sterile cotton swab. Six millimetre $(6 \mathrm{~mm})$ diameter wells were punched using cork borer in agar and filled with the desired concentrations (30 $\mathrm{mgml}^{-1}, 20 \mathrm{mgml}^{-1}$ and $10 \mathrm{mg} / \mathrm{ml}^{-1}$ ) of the extracts. Commercial antibiotics (augmentin $(30 \mu \mathrm{g})$ and gentamicin $(10 \mu \mathrm{g})$ Abtek Code NO. GC 20/p) were used as reference standards to determine the sensitivity of the isolates. Discs were directly placed onto the bacterial culture. The plates were allowed to stand for $2 \mathrm{~h}$ at room temperature for extract to diffuse into the agar and then incubated at $37^{\circ} \mathrm{C}$ over night. Antibacterial activities were evaluated by measuring inhibition zone diameters. The entire test was conducted in duplicate.

\section{Determination of MIC and MBC}

Minimum inhibitory concentrations (MICs) and minimum bactericidal concentrations (MBCs) of the plant extract were determined using agar dilution technique as described by Musa et al. (2000). The required extract concentrations were prepared in $20 \mathrm{ml}$ sterile melted Mueller-Hinton agar each and poured aseptically into sterile Petri dishes $(90 \mathrm{~mm})$ in duplicates and allowed to solidify. Sterile filter paper discs (6 mm diameter) were aseptically placed firmly on the agar in triplicate per organism. Using a micropipette, $20 \mu \mathrm{l}$ of the standardized inoculums was then placed on the paper discs aseptically and incubated at $37^{\circ} \mathrm{C}$ for $18 \mathrm{~h}$. The lowest concentration that inhibited growth around the edges of the filter paper discs was taken as the MIC. Filter paper discs in the determination of MIC that showed no visible growth around their edges were sub cultured into Mueller-Hinton broth (supplemented with 3\% Tween 80 and $0.5 \%$ egg lecithin) and incubated at $37^{\circ} \mathrm{C}$ for $48 \mathrm{~h}$. Concentrations at which there was no growth or turbidity were taken as the MBCs of the plant extract.

\section{RESULTS AND DISCUSSION}

Preliminary phytochemical screening of lipophilic leaves extract of $S$. kunthiamun revealed the presence of sterols, coumarins, higher fatty acids 
and the absence of flavones, aglycone and alkaloids (Table 1). Antibacterial activity indicated by the zone of growth inhibition ranged from 6-35 $\mathrm{mm}$. S. aureus had the largest zone of inhibition (35 mm), Klebsiella spp $(28 \mathrm{~mm})$ and $A$. hydrophila $(28 \mathrm{~mm})$ at concentration of $30 \mathrm{mgml}^{-1}$, while Pseudomonas aeruginosa had the smallest zone of inhibition (9 mm) (Table 2). The MIC and MBC showed that Klebsiella spp and S. aureus had the lowest MIC (2.09 $\left.\mathrm{mgml}^{-1}\right)$, while Salmonella spp and A. hydrophila had MIC value of 4.17 $\mathrm{mgml}^{-1}$. Pseudomonas aeruginosa and E. coli had the highest MIC values of 16.67 and $8.34 \mathrm{mgml}^{-1}$ respectively. Higher $\mathrm{MBC}$ of $16.67 \mathrm{mgml}^{-1}$ was observed against $P$. aeruginosa, (Table 3 ).

Table 2: Diameter of zones of inhibition (mm) by S. kunthianum leaf extract against the bacteria

\begin{tabular}{llll}
\hline Test organism & \multicolumn{3}{c}{ Zones of inhibition(mm)/concentration $\left(\mathrm{mgml}^{-1}\right)$} \\
\hline Escherichia coli & $30 \mathrm{mgml}^{-1}$ & $20 \mathrm{mgml}^{-1}$ & $10 \mathrm{mg}^{-\mathrm{ml}^{-1}}$ \\
Staphylococcus aureus & 23 & 17 & 12 \\
Klebsiella spp & 35 & 28 & 22 \\
Salmonella spp & 28 & 21 & 16 \\
Aeromonas hydrophila & 25 & 24 & 18 \\
Pseudomonas aeruginosa & 28 & 24 & 19 \\
\hline
\end{tabular}

Values greater than $6 \mathrm{~mm}$ indicate some activity

Table 3: MIC and MBC of S. kunthianum leaf extract against the test organisms $\left(\mathrm{mgml}^{-1}\right)$

\begin{tabular}{lll}
\hline Test organism & $\mathrm{MIC}\left(\mathrm{mgml}^{-1}\right)$ & $\mathrm{MBC}\left(\mathrm{mgml}^{-1}\right)$ \\
\hline & & \\
Escherichia coli & 8.30 & 10.41 \\
Staphylococcus aureus & 2.09 & 2.09 \\
Klebsiella $\mathrm{spp}$ & 2.09 & 4.17 \\
Salmonella $\mathrm{spp}$ & 4.17 & 8.34 \\
Aeromonas hydrophila & 4.17 & 6.26 \\
Pseudomonas aeruginosa & 16.67 & 16.67 \\
\hline
\end{tabular}

Antibacterial activity of the lipophilic leave extract of $S$. kunthianum has demonstrated significant antibacterial activity against most of the test organisms. The extract was more potent on gram-positive Staphylococcus aureus with maximum zone of growth inhibition of $35 \mathrm{~mm}$, at $30 \mathrm{mg} / \mathrm{ml}$. Although gram-negative bacteria tend to have higher intrinsic resistance to most antimicrobial agents (Ndukwe et al., 2005), In spite of this, impressive activity against gramnegative bacteria was observed $(E$. coli $23 \mathrm{~mm}$, S. typhi $25 \mathrm{~mm}, K$. spp. $28 \mathrm{~mm}$ and $A$. hydrophila $28 \mathrm{~mm}$ ). Low MIC and MBC values $(2.09 \mathrm{mg} / \mathrm{ml})$ demonstrated by the extract
Table 1: Phytochemical profile of the leaf extract of S. kunthianum

\begin{tabular}{lc}
\hline Constituent & Occurrence \\
\hline Sterols/ triterpenes & + \\
Flavone aglycone & - \\
Coumarins & + \\
Alkaloids & - \\
Higher fatty acids & + \\
Glycosides & - \\
Carbohydrates & + \\
\hline
\end{tabular}

$+=$ present, $-=$ absent especially on $K$. spp. and $S$. aureus is an indication that the lipophilic phytoconstituents have bactericidal potential. Similarly, the MIC (4.17 mg/ml) and MBC (6.26 mg/ml) exhibited against Aeromonas hydrophila -a gram negative bacillus capable of causing septicemia in fish and amphibians as well as gastroenteritis, cellulitis, meningitis, bacteraemia, soft tissue infections, peritonitis, broncho-pulmonary infections, in humans with compromised immune systems (Janda 1991; Chang et al. 1997), is yet another indication of the therapeutic potentials of the lipophilic extract against such diseases. 
Owing to their popular use as remedies for many infectious diseases, plants with secondary metabolites such as terpenoids, flavonoids, coumarins and steroids have been found in vitro to have antimicrobial properties (Sibanda and Okoh, 2007; Cowan, 2002). Terpenoids for instance, are synthesized from acetate units which share origins with fatty acids. Their tremendous activities against bacteria have been reported (Ahmed et al., 1993; Barre et al., 1997; Amaral et al., 1998). It is perhaps not surprising that higher fatty acids were found present in the lipophilic extract (Table 1). Coumarins have been found to exhibits great diversity with respect to growth inhibition activity against both Gram positive and negative bacteria (Kayser and Kolodziej, 1999). Thus, the spectra of activity displayed by the crude lipophilic extract can be explained by the combined effects of terpenoids, coumarins and steroids or due to synergism. The purified components may have even more potency with respect to inhibition of microbes. Further work on the phytoconstituents isolation and purification of the bioactive components are recommended.

In conclusion, the significant activity exhibited by the lipophilic extract against clinical isolates of S. aureus $(35 \mathrm{~mm})$, E. coli $(23 \mathrm{~mm})$ Klebsiella spp and A. hydrophila $(28 \mathrm{~mm})$ and Salmonella spp $(25 \mathrm{~mm})$ that are associated with various infectious diseases, have provided scientific justification in this research for the ethno medicinal uses of the plant in Zaria, Kaduna State, Nigeria.

\section{ACKOWLEDGEMENT}

We wish to acknowledge the contribution of Ahmadu Bello University, Zaria, for providing the facilities for conducting the research.

\section{REFERENCES}

Ahmed, A.A., Mahmoud, A.A., Williams, H.J., Scott, A.I., Reibenspies, J.H. and Mabry, T.J. (1993). New Sesquiterpene $\alpha$ methylene lactones from Egyptian plant Jasonia candicans. J. Nat. Prod., 56:12761280.

Amaral, J.A., Ekins, A., Richards, S.R. and Knowles, R. (1998). Effect of selected monoterpenes on methane oxidation, denitirification and aerobic metabolism by bacteria in pure culture. Appl. Environ. Microb., 64:520-525.

Amos, S., Kolawole, E., Akah, P., Wambebe, C. and Gamaniel, K. (2001). Behavioral effects of the aqueous extract of Guiera senegalensis in mice and rats. Phytomed., 8(5): 356-361.

Barre, J.T., Bowden, B.F., Coll, J.C., Jesus, J., Fuente, V.E., Janairo, G.C. and Ragasa, C.Y. (1997). A bioactive diterpene from Lantana camara. Phytochem., 45: 321324.

Chang, C.Y. Thompson, H., Rodman, N., Bylander, J. and Thomas, J. (1997). Pathogenic analysis of Aeromonas hydrophila septicemia. Ann. Clin. Lab. Sci., 27: 254-259.

Chhabra, S. C., Shao, J. F. and Andmshiu, E. N. (1982). Antifungal activity among traditionally used herbs in Tanzania. Dares-Salaam Med. J., 68: 68-73.

Ching, F.P., Omogbai, E.K.I., Ozolua, R. I. and Okpo, S.O. (2008). Antidiarrhoeal activities of aqueous extract of Stereospermum kunthianum (Cham, Sandrine Petit) stem bark in rodents. Afr. J. Biotech., 7(9):1220-1225

Ching, F.P., Omogbai, E.K.I., Ozolua, R. I. and Okpo, S.O. (2009). Analgesic activity of aqueous extract of Stereospermum kunthianum (Cham, Sandrine Petit) stems bark. Acta Poloniae Pharmaceutica -Drug Research, 66(1):83-88.

Cowan, M.M. (2002). Plant Products as Antimicrobial Agents. Clin. Microbiol. Rev., 12: 564-582.

Dalziel, J. M. (1955). The Useful Plants of West Tropical Africa- An appendix to the Flora of West Tropical Africa. Watmongh's Ltd. Bradford. Pp. 442-446.

Gill, L.S. (1992). Ethnomedicinal uses of plants in Nigeria, University of Benin Press, Benin city, Nigeria. p. 223.

Janda, J.M. (1991). Recent advances in the study of the taxonomy, pathogenicity and infectious syndromes associated with genus Aeromonas. Clin. Microbiol. Rev., 4:397-410.

Kamanzy, A.K., M. Kone, C. Terraux, D. Traore, K. Hostettmann, and M. Dosso, (2002). Evaluation of the antimicrobial of 
medicinal plants from the Ivory Coast. Phytother. Res., 16(5): 479-502.

Karou, D., Savadogo, A., Canini, A.,Yameogo, S. Montesano, J. S., Colizzi, V. and Traore, A. S. (2006). Antibacterial activity of alkaloids from Sida acuta. Afr. J. Biotech., 5(2): 195-200.

Kayser, O. and Kolodziej, H. (1999). Antibacterial Activity of simple coumarins: Structural requirement for biological activity. Z. Naturforsch., 54c:169-174.

Monglo, D., Njongmeta, L.M., Musonggong, G., Ngassoum, M. and Nukenine, E.N. (2006). Evaluation of Anthelmintic potential of ethanolic plant extract from Northern Cameroon Against eggs and Infective larvae of Haemonchus contortus. J. Biol. Sci. 6(2):426-433.

Mothana, R.A., Lindequist, U. (2005). Antimicrobial activity of some medicinal plants of the island Soqotra. $J$. Ethnopharmacol., 96(1-2):177-181.

Musa, K.Y., Ahmed, A., Ibrahim, H., Arowosaiye, G. and Olonitola, O.S. (2000). Phytochemical and antimicrobial studies of leaves of Acalypha racemosa. Nig. J. Nat. Prod. Med., 4:67-69.

Ndukwe, K.C., Okeke, I.N., Lamikanra, A., Adesina, S.K. and Aboderin, O. (2005). Antibacterial activity of aqueous extracts of selected chewing sticks. J. Contemp. Dental Pract., 6(3):86-94.

Onegi, B., Kraft, C., Kohler, I., Freund, M., Jenett-Siem, K., Beye Melzig, M.F., Bienzle, U. and Eich, E. (2002). Antiplasmodial activity of naphthoquinones and one anthraquinone from Stereospermum kunthianum. Phytochem. 60(1): 39-44.

Sibanda, T. and Okoh, A.I. (2007). The challenge of overcoming antibiotic resistance: Plant extracts as potential sources of antimicrobial and resistance modifying agents. Afr. J. Biotech. 6(25):2886-2896

Sofowora, A. (1993). Medicinal plants and Traditional medicine in Africa. Spectrum Books Ltd, Ibadan, Nigeria. p. 289.

Trease, K. and Evans, W. C. (1996). Pharmacognosy, $14^{\text {th }}$ edition, Harcourt Brace and company, PTE ltd, India. Pp 504-507. 